\title{
Kazimierz Sarnecki o wojnie. Relacje magnackiego rezydenta z lat 1691-1696
}

\section{Abstrakt}

Kazimierz Sarnecki, dworzanin litewskiego magnata - Karola Stanisława Radziwiłła, sporządzał dla swojego pana pisemne sprawozdania z dworu Jana III Sobieskiego, na którym z niewielkimi przerwami przebywał w latach 1691-1696. Składają się one z systematycznie prowadzonego diariusza oraz dłuższych, listownych relacji. Sarnecki pisze w nich o sprawach, które interesowały jego patrona (zdrowie króla, życie dworskie, nominacje na urzędy państwowe, sprawy wojenne), o sobie wspomina rzadko.

Przedmiotem mojego zainteresowania jest sposób, w jaki Sarnecki relacjonuje wyprawę mołdawską Sobieskiego z 1691 roku (w której uczestniczył osobiście), późniejsze walki polsko-tatarskie na Podolu, bitwy toczone na innych frontach Ligi Świętej oraz wojnę dziewięcioletnią (to wydarzenie zna wyłącznie z drugiej ręki).

Wyprawę mołdawską opisuje kompetentnie. Podobnie jak autorzy oficjalnych, wojennych diariuszy, wymienia etapy przemarszu, ugrupowanie wojsk, a w relacjach bitew widać fachowość. O zabitych informuje bardzo ogólnikowo, akcentuje tylko straty poniesione przez jednostki z Wielkiego Księstwa Litewskiego. Podkreśla aktywny udział w walkach oddziałów litewskich. Nie kryje trudności zaopatrzeniowych, choć winy nie zrzuca na Sobieskiego. Powtarza również - jak czynili inni autorzy wojennych wspomnień - pogłoskę o cudownym zdarzeniu podczas kampanii. Relacje o przyrodzie ogranicza do jej wpływu na działania wojenne; podobnie patrzy na mijane budowle - przez pryzmat ich militarnej użyteczności.

Relacje wojenne z czasów późniejszych (1692-1696) są już inne. Dominują w nich sprawy cywilne, zaś o walkach z Tatarami czy bitwach na zachodzie Europy Sarnecki wspomina nieregularnie i zdawkowo.

Słowa kluczowe: Rzeczypospolita Polska, XVII wiek, diariusz, wojna, wyprawa mołdawska 1691, Jan III Sobieski, Liga Święta, wojna dziewięcioletnia, Kazimierz Sarnecki, Karol Stanisław Radziwiłł, literatura polska XVII wieku.

\section{Nadawca, adresat, dzieło}

Kazimierz Sarnecki (zm. po 1712) - sekretarz królewski i stolnik witebski — jest postacią mało znaną, a wszystko, co wiemy o jego życiu, zawiera zwięzły biogram w Polskim Słowniku Biograficznym (Sarnecki Kazimierz 1987: 208-209). W dziejach staropolskiego pamiętnikarstwa zapisał się jako autor relacji z dworu Jana III So- 
bieskiego, na którym przebywał w latach 1691-1696 jako rezydent podkanclerzego litewskiego Karola Stanisława Radziwiłła ${ }^{1}$. Ponieważ ordynat nieświeski spokrewniony był z monarchą (Karol Stanisław to syn siostry Sobieskiego, Katarzyny) oraz przynależał do stronnictwa regalistycznego, jego dworzanin miał ułatwiony dostęp do króla, a co za tym idzie mógł efektywniej załatwiać zlecone mu przez patrona sprawy oraz łatwiej docierać do interesujących go informacji.

Jednym z zadań Sarneckiego było regularne informowanie podkanclerzego litewskiego o wszystkim, co działo się na dworze. Nie znamy treści instrukcji, jaką Radziwiłł niewątpliwie przygotował dla swego rezydenta, możemy jednak zasadnie domniemywać, że jednym z jej elementów było zalecenie pozyskiwania wszelkiego rodzaju wiadomości oraz wysyłanie ich patronowi (Czapliński, Długosz 1976: 181185; Gajdka 2009: 155-160; Żojdź 2012: 109-110); stolnik witebski w żadnym razie nie mógł pozwolić sobie na swobodę pisania sobie a Muzom, zmuszony do realizowania tego, co zostało mu nakazane. Nie mógłby stwierdzić — jak swego czasu Samuel Maskiewicz - „sam sobie gędę, / sam wesół będę” (Maskiewicz, Maskiewicz 1961: 93), nie zapisywał bowiem swobodnie prowadzonych gawęd przeznaczonych dla grona znajomych, nie myślał również o potencjalnym pożytku potomków (których zresztą zapewne nie posiadał) - za powstaniem diariusza stała wola magnata i jego potrzeby, Sarnecki zaś starał się jak najlepiej do wymogów tych dopasować ${ }^{2}$. Nie był on zresztą jedynym informatorem, Karol Stanisław Radziwiłł czerpał wiedzę z wielu źródeł (Wagner 2014: 128).

Stolnik witebski swe zadanie traktował bardzo poważnie. Skrupulatnie prowadził diariusz, w którym każdego dnia odnotowywał stan spraw publicznych (postępy wyprawy mołdawskiej, a później zdrowie monarchy, relacje między królem a jego żoną i dziećmi, posunięcia dyplomatyczne, przesunięcia w obrębie stronnictw politycznych, powstałe wakanse, dworskie uroczystości), nie skąpił również plotek czy rozmaitych ciekawostek, nawet jeśli ich związek ze sprawami publicznymi był znikomy. Warto zauważyć, że zakres zainteresowania autora jest tak szeroki, że Jadwiga Rytel określiła swego czasu jego narrację mianem „wszystkoistycznej” (Rytel 1962: 165; szerzej o zagadnieniu zob. Ślęczka 2017). Co jakiś czas sporządzone zapiski zbierał, zaopatrywał w list, w którym prostował i uzupełniał podane w diariuszu informacje, dodawał pozyskane odpisy pism, które mogły zainteresować adresata (nierzadko zaś inkorporował ich treść wprost do diariusza lub listu; o powszechności takiej praktyki zob. Borek 2001: 29-81), po czym tak sporządzony pakiet wysyłał patronowi. Przyjęta metoda pisania sprawia, że na dorobek stolnika witebskiego należy spojrzeć przez pryzmat dwu odrębnych gatunków: przynależącego do pamiętnikarstwa diariusza oraz listu.

U schyłku XVII stulecia diariusz był w polskim pamiętnikarstwie zjawiskiem już zadomowionym, Sarnecki mógł więc odwoływać się w swej praktyce pisarskiej do

${ }^{1}$ Najobszerniej o księciu podkanclerzym zob. Rachuba 1987: 240-248.

2 O powszechności tego zjawiska w epistolografii upewniają ustalenia Stefanii Skwarczyńskiej (2006: 105). 
ustalonych wzorców narracji (o diariuszu zob. Dziechcińska 1998; z nowszych prac Bauer 2007 - tam też szersza literatura przedmiotu) ${ }^{3}$. Spośród rozmaitych odmian prozy pamiętnikarskiej wyróżnia go metoda relacji uteraźniejszonej (Trzynadlowski 1961: 578-579; omówienie różnych propozycji typologii prozy pamiętnikarskiej zob. Borek 2012: 32-34). Relacje Sarneckiego spisywane były na bieżąco, dzień po dniu i zawierały wszystko to, co zdołał zobaczyć na własne oczy lub o czym udało mu się dowiedzieć od kompetentnego świadka. Siłą rzeczy zatem autorska perspektywa jest niejako skrócona, zaś ogląd pozbawiony możliwości formułowania sądów o charakterze uogólniającym; nie wiemy zresztą, czy książę podkanclerzy tego od swego rezydenta oczekiwał, albowiem nawet w listach — posługujących się nieco szerszym polem widzenia - stolnik witebski nieczęsto wykracza poza ramy chłodnej, zobiektywizowanej narracji, skoncentrowanej na sprawach dziejących się tu i teraz. Warto jednak zaznaczyć, że to w listach pozwala sobie na obszerniejsze zdawanie sprawy z własnych posunięć oraz zwraca się do adresata z pewnymi sugestiami, one więc są dla niego podstawową formą kontaktu z patronem, diariusz zaś pełni raczej rolę informacyjną (o liście zob. Skwarczyńska 2006).

W tej swoistej mieszance diariusza oraz listu tkwi pewna odmienność pism Sarneckiego od innych utworów zbliżonego rodzaju. Diariusze oficjalne, sporządzane w trakcie wojennych wypraw (na przykład Diariusz 1996, 1999, 2006), oraz prywatny, ale pisany przez jednego z dowódców (Kątski 2003), zdradzają największe podobieństwo, jednak stolnik witebski ani razu nie pozwoli sobie na zapisanie uwagi „nic nowego” (na przykład Diariusz 1999: 99), wola magnata obligowała go bowiem do notowania, a brak notatki mógł świadczyć o nienależytej staranności piszącego ${ }^{4}$. Nie są one również napisane z myślą o konkretnym odbiorcy, jak ma to miejsce w wypadku pism Sarneckiego — jego diariusz zdradza cechy typowe dla listu, w którym - jak ustaliła to Stefania Skwarczyńska — obok właściwego autora, podpisanego pod tekstem, można zasadnie mówić o współautorstwie odbiorcy:

Adresat jest biernym współautorem listu; twórca w odczuciu jego indywidualności nagina list, modyfikując i zawartość, i formę. List, który by grzeszył niedostosowaniem się do osoby adresata, byłby nienaturalny i estetycznie wadliwy. (Skwarczyńska 2006: 51)

Wskazane zjawisko jest szczególnie wyraźne w sytuacji znaczącej różnicy w hierarchii społecznej - między Sarneckim a jego patronem zieje przepaść, więc tym usilniej musi on dostosować się do życzeń czytelnika. Nie jest to cecha, której oczekujemy po diariuszu, a jedynym równie wyrazistym przypadkiem jest ujęty w formę listowną diariusz Jana Piotrowskiego (1894). Sarnecki oczywiście musiał liczyć się z tym, że adresat podzieli się treścią otrzymanej korespondencji z innymi osobami;

${ }^{3} \mathrm{~W}$ obiegu czytelniczym krążyła znacząca liczba tego rodzaju utworów, sporządzanych z różnych okazji (między innymi wojenne, sejmowe), a do tradycji rodowej jego patrona, Karola Stanisława Radziwiłła, należało utrzymywanie korespondentów donoszących o interesujących sprawach zarówno w formie listownej, jak i poprzez regularnie pisane diariusze (Jarczykowa 1998: 31-36; Gajdka 2008).

${ }^{4}$ Obawa przed gniewem patrona z powodu braku informacji nie była płonna, sam Sarnecki musiał się tłumaczyć z nadmiernej - zdaniem księcia podkanclerzego - zwięzłości. 
nie byłoby to niezwykłe, ponieważ zarówno diariusze, jak i prywatne listy krążyły w przestrzeni publicznej (Jarczykowa 2011).

Przedmiotem mojego zainteresowania jest sposób relacjonowania wojennej rzeczywistości na kartach pism stolnika witebskiego. Diariusz i listowne relacje traktuję łącznie, gdyż trudno się doszukać między nimi realnych różnic - w praktyce pisarskiej Sarneckiego zlewają się one w pewien sposób w jedną metodę. Historycy pytali dotąd „co” pisał rezydent księcia podkanclerzego, ja zapytam „jak”. Swoistość Sarneckiego lepiej ujrzymy w zestawieniu z wybranymi diariuszami XVII wieku (oraz jednym szesnastowiecznym, który - co ciekawe - jest najbardziej podobny naszemu). Z repertuaru możliwości narracyjnych autor wybiera elementy najbardziej mu pasujące, z niektórych zaś rezygnuje, tworząc z nich spójną i narastającą w czasie relację o ostatnich latach panowania Sobieskiego.

Tematyka wojenna przewija się przez karty dzieła w sposób nierównomierny. Najwięcej znajdziemy jej na początku, kiedy Kazimierz Sarnecki przesyła swemu patronowi informacje z wyprawy mołdawskiej z 1691 roku, znacznie zaś mniej w kolejnych latach, gdy przebywając na dworze Jana III Sobieskiego, składał regularne relacje o docierających tam wieściach zarówno o walkach polsko-tatarskich na Podolu, militarnych porażkach i sukcesach innych państw Ligi Świętej, jak i wiadomościach z niedotyczącej bezpośrednio Rzeczypospolitej wojny Ligi Augsburskiej z Francją. Kwestie militarne - poza wspomnianym diariuszem kampanii 1691 nie są dlań jednak pierwszoplanowe, od roku 1692 zdecydowanie dominują sprawy natury cywilnej; zapewne z uwagi na tę niejednolitość tematyczną praca Sarneckiego nie stała się przedmiotem zainteresowania monografisty polskich pamiętników wojennych XVII wieku (Bauer 2007).

$\mathrm{Z}$ mojego punktu widzenia najciekawsze są relacje z wyprawy mołdawskiej właśnie z uwagi na osobisty udział Sarneckiego (pozostałe wieści, aczkolwiek dotykające ważnych dla państwa spraw, pochodzą z drugiej ręki i mogą świadczyć co najwyżej o tempie rozchodzenia się podobnych informacji oraz zakresie publicznie dostępnej wiedzy na ich temat). Ta część diariusza różni się też od kolejnych jego partii - materiał jest tu bardzo skoncentrowany, ograniczony tematycznie do zagadnień stricte militarnych (diariusz po 1691 roku jest już inny — wielowątkowy).

Te wojenne relacje Sarneckiego były już przedmiotem zainteresowania badaczy czasów Jana III Sobieskiego. Literaturoznawcy sięgali po nie niezbyt często, na ogół ograniczając się do zwięzłych wzmianek (Woliński 1958; Rytel 1962; Sajkowski 1964, 1984) lub ujęcia pewnych elementów obrazowania (Ślęczka 2015, 2017). Znacznie chętniej do pism stolnika witebskiego sięgają historycy, dla których stanowi on wiarygodne źródło o schyłku panowania Jana III (między innymi Czapliński 1979; Królikowski 2000; Wagner 2002: 155-163), jednak i oni nie poświęcili mu odrębnego opracowania. 


\section{Sine ira et studio, czyli Kazimierz Sarnecki donosi z pola walki}

\subsection{Ostatnia wyprawa króla Jana}

Wyprawa mołdawska Sobieskiego z 1691 roku nie ma jak dotąd szczęścia u badaczy dziejów i wciąż czeka na monografię (omówienie dotychczasowej literatury przedmiotu zob. Wagner 2015: 81-845). Przygotowywano ją w pośpiechu z uwagi na skomplikowany układ polityczny w Europie oraz realne niebezpieczeństwo, że Austria, filar Ligi Świętej, zdecyduje się na zawarcie pokoju z Turcją; w Warszawie obawiano się, że jego warunki nie będą dla Rzeczypospolitej korzystne, a cały dotychczasowy wysiłek pójdzie na marne.

Przygotowania wojenne z pozoru rokowały jak najlepiej. Sejm roku 1690 uchwalił znaczący, trzydziestotysięczny komput oraz dodatkowe kwoty na pokrycie zaległości wobec wojska. Opracowano realny plan działań, liczący się z możliwościami (za cel kampanii przyjęto podporządkowanie Mołdawii, kierunkiem działań były więc Jassy - stolica hospodarstwa). Jednak realizacja tych zamiarów nie przebiegła już tak pomyślnie. Pieniędzy zebrano mniej, więc ani nie udało się zaspokoić długów, ani też należycie wyekwipować już wystawionych oddziałów, których liczba sięgnęła jedynie połowy przewidzianego sejmową konstytucją etatu. Rokowania z Austrią (Sobieski chciał uznania przez cesarza polskich praw do Mołdawii) toczyły się opornie, a obiecywana przez Leopolda I pomoc miała się wkrótce okazać tylko mirażem, podobnie jak nadzieje na dywersyjne uderzenie wojsk moskiewskich na Krym i Oczaków - ani Austria, ani Rosja nie były zainteresowane wzmacnianiem pozycji Rzeczypospolitej w tej części Europy.

Mimo tych trudności Sobieski zdecydował się wyruszyć i po zebraniu wojska oraz naradzie wojennej 24 sierpnia 1691 roku rozpoczęło się forsowanie Dniestru. Około 25 tysięcy żołnierzy przekroczyło graniczną rzekę w najlepszym porządku. Osiągnięto wprawdzie pewne sukcesy (zajęto wiele istotnych miejscowości na północy kraju, między innymi Neamt, Suczawę i Sorokę), jednak wyprawa zakończyła się niepowodzeniem: Jass nie zdobyto, zaś w trakcie uciążliwego przemarszu przez Bukowinę utracono znaczną część armii. Zabrakło zaopatrzenia oraz uzupełnień; znacznie pogorszyła się również pogoda (wyprawa rozpoczęła się zdecydowanie za późno). Dla Rzeczypospolitej bilans kampanii okazał się fatalny, zaś realne korzyści odniosła tylko Austria - polskie uderzenie na Mołdawię odciągnęło znad Dunaju znaczne siły tureckie, co ułatwiło cesarzowi zwycięstwo nad podzielonym przeciwnikiem (19 sierpnia 1691 pod Slankamen).

${ }^{5}$ Niedawno ukazało się wprawdzie poświęcone jej dzieło (Smolarek 2015), powstało ono jednak w 1948 (sic!); współczesny wydawca poszerzył je o wstęp, posłowie oraz najnowszą literaturę przedmiotu. Warto mieć na uwadze, że autor nie sięgnął po diariusz Sarneckiego, który wówczas znajdował się we Lwowie i nie był dostępny dla polskich historyków. 


\subsection{Uczestnik czy obserwator?}

Na podstawie zachowanych relacji Sarneckiego z wyprawy 1691 nie sposób jednoznacznie wywnioskować, w jakim charakterze w niej uczestniczył. Najprawdopodobniej należy w nim widzieć biernego obserwatora tych zdarzeń, albowiem w zachowanym materiale nic nie przemawia za tym, by z szablą, muszkietem czy choćby krócicą w dłoni osobiście walczył z wrogiem. Gdyby przyszło mu stawać w potrzebie, na pewno by tego nie przemilczał, jako że podkreśliłby tym samym swe zaangażowanie w sprawy patrona (w kolejnych partiach dzieła wyraźnie widać demonstracyjnie akcentowaną staranność w pańskiej służbie), a skoro napomyka, że jego pachołek został raniony podczas furażowania (Sarnecki 1958: 231), tym bardziej wspomniałby o sobie.

Pewną pomocą mogłoby się okazać ustalenie, w której jednostce lub choćby miejscu obozu przebywał. Sam diarysta niestety skąpi informacji na ten temat, jednak z przypadkowej wzmianki z 27 września wolno wnosić, że przynajmniej wtedy (a może i przez cały czas) przebywał w obozie wojsk koronnych przy królu: „To miasteczko na prawej ręce wojska naszego, tak że ledwie nie przytykało wojsko W.Ks.L. na lewej nas ręce” (Sarnecki 1958: 11). O ile bowiem pod pojęciem „wojska naszego” kryć się może ogólne określenie całej armii Rzeczypospolitej, to ze stwierdzenia „po lewej nas ręce” można się domyślać, że diarysta patrzy z perspektywy miejsca, w którym się znajduje - i jest ono odrębne od zajmowanego przez chorągwie litewskie, a ich posunięcia widzi jakby z oddali. Skoro więc wydaje się, że nie przebywa jednak przy chorągwi swego patrona, ostrożnie możemy przyjąć, że rezydował w otoczeniu głównodowodzącego.

\subsection{Litwini a Koroniarze}

Kazimierz Sarnecki, podobnie jak Karol Stanisław Radziwiłł, pochodził z Wielkiego Księstwa Litewskiego. Nie powinien więc dziwić manifestowany czasami lokalny, litewski patriotyzm, który ujawnia się niemal wyłącznie w związku z tematyką wojenną ${ }^{6}$. Najwięcej tych uwag znajdziemy oczywiście w tych partiach diariusza, które obejmują okres wyprawy mołdawskiej, natrafimy jednak na nie również później — podczas okazjonalnie zamieszczanych wzmianek o walkach na Podolu.

Sarnecki, gdy tylko może, akcentuje wkład litewskich żołnierzy w odnoszone sukcesy lub też - kiedy sukcesów brakowało - ich mężną postawę . Podkreśla, że

${ }^{6}$ Poza tym kontekstem właściwie nie szuka okazji, by mieszkańców ziem koronnych ukazać w gorszym świetle. Jedyna uwaga, która mogłaby za taką zostać uznana, pochodzi z relacji z 13 maja 1693 roku i dotyczy cichego ślubu Kazimierza Czartoryskiego z Izabelą Elżbietą Morsztynówną, która - jak dorzuca mimochodem - „nad zwyczaj dam polskich wesoła i bez wszelkiego kwasu przy ślubie” (Sarnecki 1958: 239).

7 Warto nadmienić, że to akcentowanie litewskich osiągnięć znajduje pokrycie w faktach: podczas wyprawy mołdawskiej oddziały z Wielkiego Księstwa Litewskiego istotnie wykazały się na polu bitwy i na pewno wstydu swej ojczyźnie nie przyniosły (Wagner 2014: 15). 
z Tatarami walczyli Litwini (Sarnecki 1958: 6, 7), że to litewskie działa spędziły Tatarów (Sarnecki 1958: 8), że Litwini wykazali się podczas przeprawy (Sarnecki 1958: 231). Wspomina również o stratach wojska $z$ Wielkiego Księstwa, koncentrując się - co nie budzi przecież zdziwienia - na chorągwi pancernej podkanclerzego litewskiego (Sarnecki 1958: 6). Pewna ledwo uchwytna nutka satysfakcji pobrzmiewa w relacji o rajtarach koronnych, którym w nocy zdradzieccy przewodnicy ukradli konie, oraz o Koroniarzach, których na nogi poderwał widok jednego Tatara (Sarnecki 1958: 10, 17). Zaznacza ponadto, że głód był większy wśród Litwinów, oraz podkreśla szczególne znużenie wojsk litewskich (Sarnecki 1958: 14, 21). Być może $\mathrm{w}$ ten sposób stawia dowództwu dyskretnie sformułowany zarzut swoistej dyskryminacji rodaków (za aprowizację odpowiadał przecież sztab), może też wskazuje, że to Litwini mocniej zaangażowali się w walki, czym w pewien sposób niwelowałby złą opinię na ich temat, ciągnącą się jeszcze z czasu wyprawy wiedeńskiej 1683 roku, kiedy nie tylko nie dotarli pod stolicę Austrii, lecz także narobili po drodze mnóstwo szkód: splądrowali część Węgier, a w województwie krakowskim zachowywali się jak w kraju podbitym (Podhorodecki 1983: 183). Wprawdzie Sarnecki pisał dla jednego adresata, mimo to liczył się z możliwością udostępnienia swych pism innym osobom, a zatem mógł zadbać o właściwe naświetlenie litewskiego wkładu w kampanię (zwłaszcza że w momencie sporządzania diariusza klęska wyprawy nie była przecież przesądzona).

Te wczesne pisma Sarneckiego nie upoważniają jednak do doszukiwania się śladów jakiegoś antagonizmu między żołnierzami z różnych prowincji Rzeczypospolitej; są to co najwyżej drobne przytyki, które nigdy nie osiągają większego rozmiaru. Podobnie będzie zresztą i później, kiedy Sarnecki - choć przebywa poza terenem walk - będzie narzekać na niedocenianie litewskiego wkładu w zwycięstwo oraz męstwa jego rodaków. Okazją stanie się zwycięstwo pod Uścieczkiem 6 października 1694 roku i przysłana z Wilna drukowana relacja na jego temat (Sarnecki 1958: $160)^{8}$. Wiktoria wprawdzie nie była zbyt okazała, ale na tle ogólnej mizerii schyłku panowania Jana III, kiedy to znaczącym sukcesem nazywano przejęcie konwoju z zaopatrzeniem dla Kamieńca, trzeba się było kontentować tym, co było dostępne. Pretensje stolnika witebskiego dotyczyły nie samego druku (ten bowiem litewską odwagę ukazywał we właściwym świetle), a krążących wcześniej nieżyczliwych Litwinom opinii na dworze Sobieskiego, a także pomijaniu litewskich wodzów oraz żołnierzy przez osoby wspominające o bitwie ${ }^{9}$.

${ }^{8}$ Jednak o tym, że była to niezbyt obszerna broszura (składała się ze strony tytułowej i trzech stron), już nie wspomina.

${ }^{9}$ Gdyby spojrzeć na karty wspomnianego diariusza prowadzonego przez Jana Piotrowskiego, bez trudu zauważymy ślady tej samej postawy, tyle że zwróconej w przeciwnym kierunku — pochodzący z Korony sekretarz Batorego z pewną niechęcią patrzy na Litwinów i skrupulatnie notuje, kiedy pochodzący z Wielkiego Księstwa dygnitarze oraz szeregowi żołnierze okazali się nieużyci bądź też niegodni zaufania (jednak i on nie mnoży pretensji); znamienna jest jego refleksja, iż Litwini „nieużyci są i w małych rzeczach" (Piotrowski 1894: 19). 


\subsection{W marszu i na polu bitwy}

W kwestiach wojennych Sarnecki najprawdopodobniej nie był zupełnym amatorem, albowiem relacje z działań Sobieskiego w Mołdawii zdradzają obycie z domeną Bellony (Wagner 2002: 158-159). Szeroko i ze znawstwem omawia działania wojsk Rzeczypospolitej: relacjonuje przemarsze, ustawienie do bitwy, toczone walki, wysyłane podjazdy, przeprawy przez rzeki, przesłuchania jeńców, warunki terenowe oraz ich wpływ na posunięcia polskiego dowództwa. Często akcentuje porządek: „odwód przy tym porządny”, „dobrym porządkiem [...] wojsko litewskie przeprawiło”, „wojsko ordynowane [...] wielkim porządkiem” (Sarnecki 1958: $4,8)$. Aprobata dla staranności dowództwa przebija również z opisów precyzyjnie rozmieszczonych wojsk i ich manewrów oraz z obrazu zagniewanego Sobieskiego, kiedy to kilka chorągwi wyłamało się z szyku i bez rozkazu ruszyło w pole (Sarnecki 1958: 17). Patrząc zatem na całą dobrze pomyślaną, wyposażoną oraz dowodzoną wyprawę $^{10}$, trudno pogodzić się z jej bardzo skromnymi rezultatami — bo o nich Sarnecki nie wspomni, co wynika raczej z niekompletności zachowanego materiału (ostatni list nosi datę 5 października, ostatni wpis w diariuszu -18 października, wyprawa zaś zakończyła się w pierwszych dniach listopada). Sposób, w jaki Sarnecki informuje o tych zagadnieniach, zdradza znaczące podobieństwo z ukształtowaniem narracji u Marcina Kątskiego (również uczestnika wyprawy mołdawskiej) - autora diariusza kampanii wiedeńskiej 1683 roku. Generał artylerii koronnej, profesjonalista w każdym calu, zwraca uwagę na te same elementy, choć relacjonuje je nieco obszerniej (Kątski 2003); podobnie czyni anonimowy autor relacji spod Smoleńska (Diariusz 1999: 71-72).

Współczesny nam historyk wojskowości zaznacza, że Sarnecki niewiele miejsca poświęca stratom (Wagner 2002: 160). Nie jest to niezwykłe, choć istotnie diariusze zawierają na ogół więcej tego rodzaju informacji (Piotrowski 1894: 81, passim; Diariusz 1999: 85, 106, passim; Kątski 2003: 58, passim). Z jego zapisków trudno oszacować, ilu żołnierzy poległo podczas walk, albowiem ofiary wśród Polaków w ogóle pomija, zaś zabitych Litwinów wylicza dość oszczędnie: „Z tych trzech chorągwi litewskich zginęło towarzystwa 14, pachołków 20, rajtarów 4" - podczas gdy w walce brało udział znacznie więcej jednostek. Imiennie wyliczy poległych towarzyszy z chorągwi Karola Stanisława Radziwiłła (Sarnecki 1958: 6, 230) oraz osobno napisze o śmierci dzielnego rotmistrza Wacława Iskry ${ }^{11}$ oraz murzy Arsłana Orakuła (Sarnecki 1958: 5, 6). Od czasu do czasu wspomni również o rannych

${ }^{10}$ Sam o tym wspomina w pierwszej zachowanej relacji: „Nad spodziewanie okryte są chorągwie tak polskie, jako i cudzoziemskie, ledwo 6 by ich wybrakował, na piechotach barwa nowa" (Sarnecki 1958: 227). Po miesiącu walk odnotuje jednak sporą zmianę: „[...] pod wszystkimi chorągwiami, począwszy od pańskich, komputu zupełnego nie masz" (Sarnecki 1958: 232).

11 Wydarzenie to tak mocno zapadnie mu w pamięć, że informując w 1693 swego patrona o postępach jednego z patroli zaznaczy, że „podjazd [...] się wrócić musiał zza Bukowiny, obaczywszy kupę niemałą jakichsi ludzi na tym miejscu, kędy tak dwie lecie nieboszczyk p. Iskra zginął” (Sarnecki 1958: 39). 
(Sarnecki 1958: 5). Jego perspektywa przypomina oszczędny sposób, w jaki hetman polny koronny Stanisław Żółkiewski informował o stratach podległych mu oddziałów (Żółkiewski 1966: passim). Czy więc i w ten sposób pośrednio nie ujawnia się też miejsce pobytu autora (otoczenie króla), który automatycznie przejmuje punkt widzenia wodza naczelnego?

O przeciwnikach pisze wyłącznie w kontekście toczonych walk, taktyki wroga nie analizuje, nie czyni również żadnych dodatkowych obserwacji - książę podkanclerzy Tatara w życiu widział zapewne niejednego, mimo dość młodego wieku brał udział w walkach z tymi koczownikami i najwyraźniej nie potrzebował dodatkowych informacji o ich wyglądzie, stroju czy sposobach walki. Przez kolejne zdania nie przebijają żadne emocje związane $z$ wrogiem ${ }^{12}$. Jest to zresztą element wspólny dla wszystkich diariuszy podróżnych (a wyprawa mołdawska, mimo że wojenna, była przecież także swego rodzaju podróżą) - ich autorów cechował „gust do niezwykłości", zaś sprawy znane i widziane na co dzień nie stanowiły atrakcji (Dziechcińska 1991: 22).

\subsection{Wojenne niedole}

W trakcie marszu wojsk Rzeczypospolitej przez mołdawskie bezdroża stosunkowo szybko ujawnił się nieodłączny towarzysz każdej ówczesnej armii działającej na obcym i rzadko zaludnionym terenie, czyli niedostatek zaopatrzenia. Sarnecki zwięźle informuje, że w litewskim wojsku „większy głód” (Sarnecki 1958: 14) oraz cytuje zdanie jednego z radzących 18 września dygnitarzy, że „Wojsko już się skarży na głód, osobliwie piechoty bardzo głodne, która z jednej kradzieży żyje” (Sarnecki 1958: 231). Poza tym często nadmienia, jak to furażerowie rozjeżdżali się po okolicy szerokim kręgiem w celu pozyskania żywności oraz paszy. Zaznacza wiążące się z tym niebezpieczeństwo ze strony krążących po okolicy i szarpiących naszych żołnierzy Tatarów oraz Mołdawian (w podobnych okolicznościach sam niemal utracił pachołka), wspomina również o bezskutecznym oczekiwaniu na ciągnące z zaplecza frontu zaopatrzenie (Sarnecki 1958: 12, 14, 231). Jak żywo przypomina to niedolę oblegających Psków żołnierzy armii Batorego - wzmianki o coraz dalej sięgających wyprawach po żywność stanowią nieodłączny element narracji (Piotrowski 1894: 95, 111, 132, passim).

O ludności miejscowej niemal nie wspomina, nie zastanawia się również, dlaczego nie wspomaga ona Polaków, a wręcz przeciwnie - prowadzi wspomnianą wojnę szarpaną (Nowak, Wimmer 1981: 535).

Kłopotliwy był nie tylko niedostatek żywności (co w pewnym stopniu wynikało z zaniedbań polskiego dowództwa), lecz także pogoda. Ta była zmienna (kampania toczyła się wszak w porze późnego lata oraz wczesnej jesieni), przechodząc od

12 Jakieś emocje musiał jednak żywić, albowiem znacznie później, informując adresata o pożarze Konstantynopola, zdradzi targające nim uczucia: „daj Boże, żeby i wszyscy zgorzeli poganie” (Sarnecki 1958: 63). 
stosunkowo suchej na początku wyprawy do znacznie gorszej w jej późniejszej fazie. W liście z 19 września Sarnecki pochwali: „Tym tylko P. Bóg wygadza, że w tej tam pustyni deszcz nam nie przeszkadza” (Sarnecki 1958: 231), jednak już w notatce $\mathrm{z}$ następnego dnia znajdziemy wzmiankę: „W nocy był deszcz wielki z zimnem przykrym” (Sarnecki 1958: 8). I tak będzie przez cały czas: „mróz mały z lodem” / „dzień bardzo był gorący” / „deszcz całą noc i dzień” (Sarnecki 1958: 9, 13, 21). Nie ma wprawdzie na tle pogody aż takiej obsesji jak Jan Antoni Chrapowicki, który pracowicie dzień po dniu odnotowywał stan aury (Chrapowicki 1978), jednak o trudnościach stwarzanych przez warunki klimatyczne nie milczy. Armii przeszkadza deszcz, wadzi zimno, a i wiatr nie pomaga.

\subsection{Mirabilia}

Często spotykanym składnikiem wojennych wspomnień z XVI czy XVII stulecia są tajemnicze zjawiska oraz mistyczne zapowiedzi ważnych zdarzeń (Kroczak 2006: 122-154). Sarnecki raczej twardo stąpał po ziemi, albowiem na kartach jego pism możemy się doszukać jedynie kilku wzmianek o podobnych sprawach. Jedna z nich związana jest z kampanią 1691 roku — stolnik witebski przekazuje powtórzoną przez tatarskiego jeńca opowieść, „jakoby tam jedna Tatarka panna obumarła i trzy dni nie żyła, a potem wstawszy, praedicere miała Tatarom, że »dotądeście cudze kraje wojowali i znużeli, teraz też czas przyszedł, że w swojej ziemi ginąć będziecie od Polaków“" (Sarnecki 1958: 11-12). Nie jest to, oczywiście, tak spektakularny znak, jaki - według Piotrowskiego - miał się ukazać podczas ostatniej wyprawy Batorego (Piotrowski 1894: 62), jednak i takie krążące „proroctwo”, nawet mimo jego wyjątkowo podejrzanej proweniencji, miało w zamyśle autora podnosić morale żołnierzy. Sarnecki - inaczej niż sprawozdawca spod Pskowa - nie szuka wyjaśnienia opisywanych zdarzeń, ograniczając się jedynie do ich odnotowania. Jest to skądinąd charakterystyczna cecha pisarstwa stolnika witebskiego, który co do zasady unika komentarzy i ogranicza się do prostego powiadamiania o zaobserwowanych faktach.

\subsection{Użyteczność przed pięknem}

Uwagi o warunkach naturalnych oraz śladach ludzkiej działalności, które od czasu do czasu Sarnecki wplata w tkankę swych codziennych zapisków, podporządkowane są - co nie dziwi - nadrzędnemu celowi, czyli relacjonowaniu spraw militarnych. Nie będzie więc rozwodził się nad estetycznymi walorami mołdawskiej przyrody (załóżmy może nieco na wyrost, że to i owo mogło mu się tam zwyczajnie podobać), natomiast nie omieszka zaznaczyć wpływu ukształtowania terenu lub pogody na posunięcia walczących stron: góry to tylko przeszkoda terenowa, zaś las to albo mniej nieco niż góry uciążliwa bariera, która ogranicza możliwości działania armii, albo doskonały teren na zasadzkę. Warto zaznaczyć, że w pamiętnikarstwie „cywil- 
nym" przyrodę traktuje się diametralnie odmiennie, zaś fascynacja naturą jest tym większa, im bardziej odbiega ona od znanych z rodzimych stron realiów (o opisach przyrody w pamiętnikarstwie staropolskim zob. Dziechcińska 2003: 62-81).

Podobnie rzecz ma się z wytworami człowieka. Sarnecki dostrzega praktycznie wyłącznie te obiekty, które mogą mieć znaczenie militarne - fortyfikacje, cerkwie oraz kościoły. Wyraźnie widać to w notatce z 6 października - wspominając o potencjalnym celu marszu - miejscowości Roman, zapisuje: „przyszła relacyja, że spalony, tam żadnego monasteru nie masz, w którym by się mogło ufortyfikować, i że ziemia piaszczysta, z której się wały sypać miały, nadto że miejsce to dependent a dominio Niemca” (Sarnecki 1958: 17). Najobszerniej opisuje wspomniany „Niemiec”, czyli Neamt, koncentrując się oczywiście na jego walorach obronnych. W wypadku cerkwi i kościołów (tych pierwszych było oczywiście znacznie więcej) informuje o ich drewnianym lub murowanym charakterze. $Z$ jednej strony widać $w$ tym pewne ślady wartościowania (budowle drewniane ceniono niżej), z drugiej jednak podstawowym powodem zwracania szczególnej uwagi na materiał, z którego je zbudowano, wydaje się militarny pożytek - obiekty murowane lepiej nadają się do obrony (o sposobie deskrypcji miejsc warownych zob. Kucharski 2013: 163-171).

Co warte zauważenia, te właśnie partie pism Sarneckiego, które dotyczą szeroko rozumianej przyrody oraz wytworów działalności budowlanej człowieka, są bardzo ubogie w przymiotniki. Zapiski Sarneckiego wykazują się daleko posuniętym ascetyzmem: las będzie „niedobry do przeprawy”, „nietwardy”; góra „wielka”, „wysoka, skalista”; rzeka „skalista”, „głęboka i rwąca”; cerkiew „podmurowana”, „sklepiona”, "drewniana”, „murowana”, „piękna”; kościół „murowany, oparkaniony”, „sklepiony” (Sarnecki 1958: 18, 19, 5, 9, 20, 8, 231, 10, 11, 13, 20, 11, 13, 20, 13). Bez trudu można zauważyć, że wyjątkowo słabo reprezentowany jest podstawowy w diariuszach podróżnych przymiotnik „piękny”, którym inni autorzy hojnie szafują przy opisywaniu oglądanych budowli czy miejsc (o różnych znaczeniach tego określenia zob. Dziechcińska 2003: 78-79). W relacjach Sarneckiego z kampanii mołdawskiej pojawi się on raz - w obszerniejszej deskrypcji zdobytej forteczki w Neamt, jednak nawet i w tym wypadku zapewne nie chodziło o estetykę miejsca, a o jego użyteczność, zaś o ukształtowaniu relacji przesądziła wola odbiorcy.

\section{Wojna widziana z oddali}

\subsection{Walki polsko-tatarskie u schyłku panowania króla Jana III Sobieskiego}

Aż do pokoju w Karłowicach, czyli do stycznia 1699 roku, na południowej granicy Rzeczypospolitej nie było spokoju. Wprawdzie walki z Tatarami toczyły się ze znacznie mniejszym natężeniem niż kiedyś, jednak agresywni koczownicy z Krymu nadal stanowili istotny problem dla słabnącego państwa polsko-litewskiego. Jedynymi zaczepnymi działaniami, na jakie Korona i Litwa mogły sobie pozwolić, były 
okazjonalnie podejmowane próby przejmowania dostarczanego przez Turków zaopatrzenia dla wciąż dzierżonego przez Portę Kamieńca Podolskiego. Najczęściej jednak ograniczano się do obrony przed tatarskimi napastnikami; jej symbolem stała się założona w 1692 roku twierdza nad Dniestrem - Okopy Świętej Trójcy. Nazwa ta wielokrotnie przewija się przez karty zapisków stolnika witebskiego.

Sarnecki po zakończeniu kampanii mołdawskiej będzie (z drobnymi przerwami) przebywał na królewskim dworze. W diariuszu oraz relacjach $\mathrm{z}$ tego czasu dominuje tematyka cywilna, jednak nie ma właściwie tygodnia, żeby nie pojawiła się choć jedna wzmianka na temat zagrożenia stwarzanego przez uciążliwych koczowników. Najczęściej stykamy się z informacjami o szykującej się do wymarszu ordzie. Na dwór z różnych źródeł (poczta dyplomatyczna, raporty pogranicznych dowódców, zeznania jeńców) docierają wieści o Tatarach, którzy gromadzą siły, by jak co roku ruszyć na niszczycielską wyprawę. Czasem jej celem będzie południowa granica Rzeczypospolitej (koczownicy potrafią zagrozić nawet Lwowowi), innym zaś razem - państwo moskiewskie. Zdarzyć się też może, iż wieści okażą się plotką i czambuły w ogóle się nie pojawią. Mimo że stolnik witebski na ogół nie opatruje przekazywanych informacji komentarzem, między wierszami jego relacji można wyczuć grozę, jaką wciąż jeszcze budzili najeźdźcy z Krymu: „Jest za co Bogu dziękować, że tą prezencyją pańską ten nieprzyjaciel jest ostraszony" (Sarnecki 1958: 100) albo „Jest za co Bogu dziękować, że te kraje pod ten czas będą wolne a secunda incursione" (Sarnecki 1958: 143). Nastrój zagrożenia potęgowały pogłoski (trudne jednak do zweryfikowania), że „ten nieprzyjaciel już miał wszystek trakt do Warszawy, wsi i miasteczka popisane" (Sarnecki 1958: 206).

Źródłem kłopotów nie była zresztą tatarska potęga, bo i Chanat Krymski znajdował się u kresu swej chwały, ale dojmujący niedostatek po stronie obrońców. Brakowało właściwie wszystkiego - a zwłaszcza nervum belli, czyli pieniędzy. Sarnecki tego elementu oczywiście nie pomija i skrupulatnie relacjonuje swemu patronowi wszystkie przypadki, kiedy to udało się pozyskać jakiekolwiek środki na obronę. Podkreśli wysłanie 60 tysięcy złotych komendantowi Soroki - o bardzo złym stanie załogi donosił kilka dni wcześniej (Sarnecki 1958: 41, 35). Nie przemilczy sytuacji, kiedy Sobieski z prywatnej szkatuły wyasygnował 120 tysięcy na opatrzenie twierdz oraz zaspokojenie pretensji Kozaków, przekaże wieści o niepokojach wśród niepłatnego wojska, o kłopotach finansowych, w jakie wpadł hetman Jabłonowski, samodzielnie opłacający żołnierzy (Sarnecki 1958: 51, 55, 34, 216-217).

Mimo takich problemów żołnierze Rzeczypospolitej oczywiście walczą mężnie, choć na ogół są to drobne potyczki. Zacytujmy dla przykładu jedną z typowych informacji tego rodzaju: „Z Szańca wiadomość przyszła, że nasi okopowscy Ś. Trójcy Lipków 40 kilku zarwali i kilkadziesiąt sztuk bydła zabrali” (Sarnecki 1958: 61). Zdarzają się i zwycięstwa większe (jak choćby Jabłonowskiego i Sapiehy pod Uścieczkiem 6 października 1694 roku czy Jabłonowskiego pod Lwowem 11-12 lutego 1695 roku), jednak dominują relacje z wojny szarpanej, o starciach niewielkich oddziałów czy niedużych sukcesach i porażkach. 
Obok dzielnych dowódców pokroju hetmana wielkiego koronnego, obu hetmanów litewskich ${ }^{13}$, komendanta Soroki Ernesta Rappa czy Michała Brandta z Okopów Świętej Trójcy wciąż istotna okazuje się osoba króla Jana III. Nieodmiennie troszczy się on o zapewnienie wojsku niezbędnych środków (co prawda z marnym skutkiem), ceni dzielnych żołnierzy i zawsze jest im życzliwy, nagradza męstwo i dba o leczenie rannych (Sarnecki 1958: 234, 146, 136-137, 141), a nawet potrafi samą swą obecnością niedaleko teatru działań wojennych odstraszyć przeciwnika: „dlaczego najbardzi król jm. podobno nie spieszył się stąd, aby terrore nominis zasłaniał one od nieprzyjaciela" (Sarnecki 1958: 143). Nie sądzę, by diarysta przesadzał - sława zwycięzcy spod Wiednia jeszcze nie wyblakła, więc istotnie sama królewska obecność mogła wpłynąć mitygująco na Tatarów (wysoka ocena zdolności dowódczych Sobieskiego zob. Nowak, Wimmer 1981: 535-537; Wójcik 1983: 524-526; potwierdzenie respektu u współczesnych zob. Oramus 2012).

\subsection{Inne teatry walk}

Wspomniane walki z Tatarami stanowiły w rzeczywistości jedynie pewien element szerszego konfliktu w Europie, mianowicie wojny Ligi Świętej (do której oprócz Rzeczypospolitej należała Austria, Republika Wenecka, Państwo Kościelne oraz od 1686 roku - Rosja) z Turcją. Najważniejsze działania toczyły się poza obszarem Korony, na froncie węgierskim ${ }^{14}$. Walczono również na wschodzie, gdzie Rosja usiłowała zdobyć Azow, a także na morzu (ciężar tych walk spoczywał na flotach Wenecji i Państwa Kościelnego).

Wzmianki o sukcesach i porażkach sojuszników pojawiają się od czasu do czasu na kartach pracowicie zapełnianych przez stolnika witebskiego kolejnymi zdaniami, nie jest ich jednak zbyt dużo i można odnieść wrażenie, że istotnie w pewnym stopniu rację miał wydawca pism Sarneckiego, Janusz Woliński, który stwierdził jego niemal całkowity brak zainteresowania sprawami wykraczającymi swym zasięgiem poza granice Rzeczypospolitej (Woliński 1958: 7). Diarysta tego, o czym się dowiaduje, oczywiście nie przemilczy, jednak wyraźnie daje się odczuć pewną obojętność w stosunku do informacji z innych frontów Ligi Świętej. Wyraźnie widać, że się specjalnie do ich pozyskiwania nie przykłada - dworska polityka pociąga go znacznie mocniej. Wspomina o bitwach: wielkim zwycięstwie wojsk austriackich

${ }^{13} \mathrm{O}$ hetmanie wielkim litewskim, którym w tym czasie był Kazimierz Jan Sapieha, wyraża się pozytywnie. Jest to o tyle interesujące, że ten potężny litewski magnat, mimo że był jedną z głównych figur opozycji wobec Sobieskiego, utrzymywał bardzo poprawne stosunki z patronem Sarneckiego, podkanclerzym litewskim Karolem Stanisławem Radziwiłłem, zatem stolnik witebski nie musiał uciekać się do przemilczenia sukcesów hetmana. Sytuacja zmieni się dopiero w 1695 roku, po zgonie Ludwiki Karoliny z Radziwiłłów - księżnej neuburskiej - i rozpoczęciu sporów o pozostawione przez nią dobra na Litwie, do których pretendowali członkowie obu rodów.

14 Tam również zapadnie decydujące rozstrzygnięcie tej wojny, bitwa pod Zentą, stoczona 11 września 1697 roku, czyli już po śmierci Sobieskiego i zakończeniu misji Sarneckiego. 
pod Slankamen 19 sierpnia 1691 roku, oblężeniu Belgradu w 1693 roku, klęsce cesarskich pod Lugos 21 września 1695 roku, niepowodzeniu moskiewskich prób zdobycia Azowa na początku 1696 roku (Sarnecki 1958: 12, 257, 310, 315-316). Nie przemilczy również wzajemnej nieufności między członkami Ligi: Austrii wobec Rzeczypospolitej, Rosji wobec Korony i Litwy i wzajemnie (Sarnecki 1958: 38-39, 322-323, 327, 287). Odnotowuje też przewijającą się między innymi przez uchwały sejmikowe chęć zawarcia separatystycznego pokoju z Turcją: „[posłowie] prosili [...] o pokój, nie zapatrując się na koligatów, którzy nas in nexu ligi trzymać chcą, nam wzajemnych nie pełniąc kondycyj” (Sarnecki 1958: 242). Na tle całości zachowanej korespondencji stolnika witebskiego są to jednak przypadki odosobnione.

Odrębnym konfliktem, w którym Rzeczpospolita nie brała udziału, był toczony na polach bitewnych spór Ligi Augsburskiej z Francją. Nieco informacji na ten temat znajdziemy w okazjonalnie przesyłanych za pośrednictwem Sarneckiego awizach, on sam tego tematu właściwie nie porusza, jedynie na marginesie relacji o losie Teresy Kunegundy po wyjeździe do małżonka nadmieni, iż „gdy się ta kapitulacja Namuru skończyła, za pierwszą wiadomością w Bruksellach ks. jm. elektorowa z dział i we dzwony uderzyć kazała” (cyt. za: Komaszyński 1982: 140-141). Wspomni również o papieskich próbach doprowadzenia do zakończenia tej wojny (Sarnecki 1958: 322-323).

\section{Zakończenie}

Tematyka wojenna odgrywa istotną rolę w pismach Sarneckiego, choć poświęcone jej partie tekstu rozkładają się nierównomiernie. Dominuje oczywiście w relacjach z kampanii mołdawskiej Sobieskiego, której był uważnym, acz beznamiętnym obserwatorem, pojawia się jednak i później — stolnik witebski regularnie informuje patrona o sprawach Bellony, choć bardziej zajmują go już sprawy cywilne.

Sposób mówienia o tych kwestiach jest zbliżony do znanego z oficjalnych diariuszy XVII stulecia - autor dzień po dniu starannie odnotowuje fakty, sumiennie zbiera istotne informacje, które selekcjonuje i przekazuje dalej według nakazu swego patrona. Własnych poglądów na ogół nie ujawnia, unika również komentarzy. Podobieństwo rozciąga się też na poziom stylu; do sposobu pisania stolnika witebskiego bez wahania można zastosować ogólny wniosek Piotra Borka: „Za jego [stylu pamiętnikarskiego - T.Ś.] podstawowy wyróżnik należy zatem uznać urozmaicenie i niejednorodność stylistyczną (z dominacją stylu potocznego)" (Borek 2002: 257).

Są jednak i różnice - diariusz oraz listy Sarneckiego są do siebie wyraźnie zbliżone poprzez dominującą osobę adresata. Wola podkanclerzego litewskiego decyduje o doborze materiału oraz o kierunkach działań jego rezydenta, podczas gdy inni diaryści zazwyczaj nie musieli kierować się zamiłowaniami konkretnego odbiorcy. Dominująca pozycja Karola Stanisława z jednej strony zbliża do siebie oba uprawiane przez Sarneckiego gatunki, z drugiej zaś przesądza o jego odmienności. 


\section{Bibliografia}

\section{Źródła}

Chrapowicki J.A. (1978): Diariusz, oprac. T. Wasilewski, Warszawa.

Diariusz drogi Króla JMCi Zygmunta III od szczęśliwego wyjazdu z Wilna [...] do wzięcia zamku Smoleńsk w roku 1611 (1999): oprac. J. Byliński, Wrocław; [uzupełniony o zakończenie w:] M. Kuran, Krótkie a prawdziwe opisanie wzięcia Smoleńska. Brakujące zakończenie diariusza króla jmci Zygmunta III [...] Pod Smoleńsk, „Barok” 2010, z. 2, s. 161-167.

Diariusz kampanii smoleńskiej Władysława IV (1633-1634) (2006): oprac. M. Nagielski, Warszawa.

Diariusz oblężenia Pskowa (1996): wyd. J. Urwanowicz, „Zeszyt Naukowy Muzeum Wojska w Białymstoku" z. 10, s. 143-168.

Kątski M. (2003): Diariusz wyprawy wiedeńskiej króla Jana III w roku 1683, do druku przygotował B. Królikowski, Lublin.

Maskiewicz S., Maskiewicz B. (1961): Pamiętniki, oprac. A. Sajkowski, Wrocław.

Piotrowski J. (1894): Dziennik wyprawy Stefana Batorego pod Psków, wyd. A. Czuczyński, Kraków.

Sarnecki K. (1958): Pamiętniki z czasów Jana Sobieskiego. Diariusz i relacje z lat 1691-1696, oprac. J. Woliński, Wrocław.

Żółkiewski S. (1966): Początek i progres wojny moskiewskiej, oprac. J. Maciszewski, Warszawa.

\section{Literatura}

Bauer M. (2007): Z dziejów batalistyki polskiej. Studia nad pamiętnikami wojennymi z XVII w., Kraków. Borek P. (2001): Ukraina w staropolskich diariuszach i pamiętnikach. Bohaterowie, fortece, tradycja, Kraków.

Borek P. (2002): Szlakami dawnej Ukrainy. Studia staropolskie, Kraków.

Borek P. (2012): O polskim pamiętnikarstwie doby baroku. Rekonesans, [w:] Z dziejów staropolskiego pamiętnikarstwa. Przekroje i zbliżenia, red. P. Borek, Kraków, s. 31-52.

Czapliński W., Długosz J. (1976): Życie codzienne magnaterii polskiej w XVII wieku, Warszawa.

Czapliński W. (1979): Wstęp, [w:] J.Ch. Pasek, Pamiętniki, wstęp i objaśnienia W. Czapliński, Kraków, s. III-LXXIII.

Dziechcińska H. (1991): O staropolskich dziennikach podróży, Warszawa.

Dziechcińska H. (1998): Diariusz, [w:] Słownik literatury staropolskiej, red. T. Michałowska, Wrocław, s. $163-165$.

Dziechcińska H. (2003): Świat i człowiek w pamiętnikach trzech stuleci: XVI-XVII-XVIII, Warszawa.

Gajdka K. (2008): Stanisławowie Kurosz i Buczyński jako czołowi informatorzy księcia Krzysztofa II Radziwiłła, [w:] Komunikacja i komunikowanie w dawnej Polsce, red. K. Stępnik, M. Rajewski, Lublin, s. $295-308$.

Gajdka K. (2009): Literatura, propaganda, służba. Ludzie pióra w otoczeniu Radziwiłłów birżańskich w pierwszej połowie XVII wieku, Warszawa.

Jarczykowa M. (1998): Kultura epistolarna w kręgu Radziwiłłów birżańskich w XVII wieku, Kielce.

Komaszyński M. (1982): Teresa Kunegunda Sobieska, Warszawa.

Kroczak J. (2006): „Jeśli mię wieźdźba prawdziwa uwodzi...”. Prognostyki i znaki cudowne w polskiej literaturze barokowej, Wrocław.

Królikowski B. (2000): Wśród Sarmatów. Radziwiłłowie i pamiętnikarze, Lublin.

Kucharski A. (2013): Theatrum peregrinandi. Poznawcze aspekty staropolskich podróży w epoce późnego baroku, Toruń.

Nowak T., Wimmer J. (1981): Historia oręża polskiego 963-1795, Warszawa. 
Podhorodecki L. (1983): Wiedeń 1683, Warszawa.

Rachuba A. (1987): Radziwiłł Karol Stanisław, [hasło w:] Polski Słownik Biograficzny, t. 30, Warszawa, s. $240-248$.

Rytel J. (1962): „Pamiętniki” Paska na tle pamiętnikarstwa staropolskiego. Szkice z dziejów prozy narracyjnej, Wrocław.

Sajkowski A. (1964): Nad staropolskimi pamiętnikami, Poznań.

Sajkowski A. (1984): W stronę Wiednia. Dole i niedole wojenne w świetle listów i pamiętników, Poznań. Sarnecki Kazimierz (1987): [hasło w:] Polski Słownik Biograficzny, t. 35, Warszawa-Kraków, s. 208-209.

Skwarczyńska S. (2006): Teoria listu, na podstawie lwowskiego pierwodruku oprac. E. Feliksiak, M. Leś, Lwów.

Smolarek P. (2015): Kampania mołdawska Jana III roku 1691, do druku przygotowali Z. Hundert, M. Wagner, Oświęcim.

Ślęczka T. (2015): Marysieńka Sobieska w relacjach Kazimierza Sarneckiego, [w:] Epistolografia w dawnej Rzeczypospolitej, t. 6, red. P. Borek, M. Olma, Kraków, s. 129-143.

Ślęczka T. (2017): Świat zainteresowań siedemnastowiecznego magnata, [w:] Epistolografia w dawnej Rzeczypospolitej, t. 7, red. P. Borek, M. Olma, Kraków, s. 225-240.

Trzynadlowski J. (1961): Struktura relacji pamiętnikarskiej, [w:] Księga pamiątkowa ku czci Stanisława Pigonia, red. Z. Czerny et al., Kraków, s. 577-583.

Wagner M. (2001): Pamiętnikarstwo wojskowe czasów Jana III Sobieskiego (1674-1696). Próba bilansu, „Napis” 7, s. 297-311.

Wagner M. (2002): W cieniu szukamy jasności chwały. Studia z dziejów panowania Jana III Sobieskiego (1684-1696), Siedlce.

Wagner M. (2014): Udział wojska litewskiego w wojnie polsko-tureckiej w latach 1684-1699, „Historia i Świat" nr 3, s. 113-135.

Wagner M. (2015): Posłowie, [w:] P. Smolarek, Kampania mołdawska Jana III roku 1691, do druku przygotowali Z. Hundert, M. Wagner, Oświęcim, s. 77-84.

Woliński J. (1958): Od wydawcy, [w:] K. Sarnecki, Pamiętniki z czasów Jana Sobieskiego. Diariusz i relacje z lat 1691-1696, oprac. J. Woliński, Wrocław, s. V-XI.

Żojdź K. (2012): Jan Mierzeński. Klient i rezydent Bogusława Radziwiłła w latach 1656-1665, Oświęcim.

\section{Kazimierz Sarnecki on war: Accounts by a magnate's resident from 1691-1696}

\section{Summary}

Kazimierz Sarnecki, the courtier of the Lithuanian magnate, Karol Stanisław Radziwiłł, prepared for his master written reports from the court of Jan III Sobieski, at which he stayed between 1691 and 1696, with a few interruptions. They consist of a systematically kept diary and longer epistolary relations. Sarnecki writes in them about the matters that interested his patron (the king's health, court life, government appointments, war affairs), he rarely mentions himself.

The subject of my interest is the way in which Sarnecki recounts Sobieski's Moldovan expedition of 1691 (in which he participated himself), the subsequent Polish-Tatar struggles in Podolia, battles on the other fronts of the Holy League, and the Nine Years' War (these events he knows only vicariously).

He describes the Moldovan expedition completely. Just as authors of the official war diaries, he lists the stages of the march, the grouping of troops, in the reports of battles you can see the professionalism. He informs very vaguely about the killed, accentuates only losses, incurred by the forces from the Grand Duchy of Lithuania. He emphasizes active participation of Lithuanian troops in the fighting. He does not hide the difficulties with supplies, although he does not shift the blame on Sobieski. He 
will also repeat - as other authors of the war memories did - a rumour about a miraculous event during the campaign. He limits relations about nature to its impact on warfare; similarly he looks at the buildings he passes through the prism of their military utility.

War reports from later times (1692-1696) are different. The civil matters dominate, while the battles with the Tatars or battles in Western Europe Sarnecki mentions irregularly and perfunctorily.

Keywords: Polish-Lithuanian Commonwealth, 17th century, diary, war, the Moldavian expedition of 1691, Jan III Sobieski, the Holy League, the Nine Years' War, Kazimierz Sarnecki, Karol Stanisław Radziwiłł, 17th-century Polish literature. 